\title{
LIMITING CURRENCY VOLATILITY TO STIMULATE GOODS MARKET INTEGRATION: A PRICE BASED APPROACH
}

\author{
David C. Parsley \\ Shang-Jin Wei \\ Working Paper 8468 \\ http://www.nber.org/papers/w8468
NATIONAL BUREAU OF ECONOMIC RESEARCH
1050 Massachusetts Avenue
Cambridge, MA 02138
September 2001

We would like to thank Charles Engel, Andy Rose and seminar participants at the Hong Kong Monetary Authority for very helpful comments. The views presented in this paper are those of the authors and do not necessarily reflect the views of any institution with which they are affiliated. The views expressed herein are those of the authors and not necessarily those of the National Bureau of Economic Research.

(C) 2001 by David C. Parsley and Shang-Jin Wei. All rights reserved. Short sections of text, not to exceed two paragraphs, may be quoted without explicit permission provided that full credit, including $\odot$ notice, is given to the source. 
Limiting Currency Volatility to Stimulate Goods Market Integration:

A Price Based Approach

David C. Parsley and Shang-Jin Wei

NBER Working Paper No. 8468

September 2001

JEL No. F1, F3

\begin{abstract}
$\underline{\text { ABSTRACT }}$
This paper empirically studies the effect of instrumental and institutional stabilization of the exchange rate on the integration of goods markets. An instrumental stabilization of the exchange rate is accomplished through intervention in the foreign exchange market, or by monetary policies. An institutional stabilization, is an adoption a currency board or a common currency. In contrast to the literature that employs data on the volume of trade, an important novelty of this paper is the use of a 3dimensional panel of prices of 95 very disaggregated goods (e.g., light bulbs) in 83 cities from around the world from 1990 to 2000. We find that goods market integration is increasing over time and is inversely related to distance, exchange rate variability, and tariff barriers. In addition, the impact of an institutional stabilization of the exchange rate provides a stimulus to goods market integration that goes far beyond an instrumental stabilization. Among the institutional arrangements, long-term currency unions demonstrate greater integration than more recent currency boards. All of them can improve their integration further relative to a U.S. benchmark.
\end{abstract}

David C. Parsley

Owen Graduate School of Management

Vanderbilt University, and

Hong Kong Institute for Monetary Research

David.Parsley@,Vanderbilt.edu
Shang-Jin Wei

Brookings Institution

Harvard University CID

and NBER

$\underline{\text { Swei@Brookings.edu }}$ 


\section{Introduction}

The launch of the euro - a common currency for twelve European countries - has been accompanied by great fanfare. Foremost among its proponents' claims is that it will be a great promoter of further economic integration. This paper presents a new approach to studying the effect of exchange rate stabilization on goods market integration. Our novelty is to focus on international price dispersion, rather than the trade flows typically examined in this literature. This opens up a fresh channel to assess the differential economic effects of an instrumental stabilization of exchange rates reducing volatility through intervention in the foreign exchange market or via monetary policies, versus institutional stabilization of exchange rates - reducing volatility through establishing an explicit currency board or common currency. Our approach is facilitated by a unique cross-country data set on prices of very disaggregated products (e.g., light bulbs and onions) over 1990-2000.

Understanding the size of the economic effect of exchange rate stabilization and monetary regimes is very important for open-economy macroeconomics. For example, Feldstein (1997) stated that the adoption of a single currency in Europe has costs for its member countries (loss of an independent monetary policy) but no big economic benefits. The conclusion is partly based on his reading of the empirical literature that generally reports a small effect of exchange rate stabilization on trade volumes. In contrast, Rose (2000) has recently argued that an adoption of a common currency provides a non-trivial expansion of the volume of trade that goes beyond the effect of reducing exchange rate volatility to zero. These findings, obtained from estimates of a (modified) gravity model of trade volumes, are both statistically and economically significant.

Using trade volumes and a gravity model to study goods market integration is not new per se. For example, McCallum (1995), Wei (1996), and Heliwell (1998), each use such a methodology to study the incomplete nature of international goods market integration. But Rose (2000) is the first 
paper that studies the effect of a common currency on goods market integration (see also Frankel and Rose 2000, Rose and Engel 2000, and Rose and van Wincoop 2001 for more recent extensions). According to these studies the existence of a common currency increases bilateral trade by as much as $300 \%$ over what is observed between otherwise identical countries. ${ }^{1}$

Studies based on the volume of trade have their limitations. A potential problem is that the mapping between the volume of trade and degree of market integration is not necessarily monotonic unless special assumptions are adopted. For example, as Wei (1996) pointed out, if the products of two countries are highly substitutable (e.g., red cars by country 1 and blue cars by country 2), then a small cost of trade could lead to a large reduction in trade volume. In this example the elimination of the small trade barrier (such as adopting a common currency) could lead to a large increase in trade volumes with relatively little change in welfare. In other words, depending on the relative elasticity of substitution between the goods of the countries in question, it is possible for a country pair with a larger increase in trade volume (from a currency union, for example) to have a smaller change in the degree of integration (and welfare) than another pair with a smaller increase in trade volume.

In this paper, we adopt a price-based approach - estimating the increment in welfare from the decline in the dispersion of prices of 95 very disaggregated goods (e.g., light bulbs, and soap) among 72 countries in the world. The data, from the Economist Intelligence Unit, is the most extensive set available in terms of the scope of country and goods coverage from a single source. Assimilation by a single source insures greater comparability of the goods across international locations. Unlike the potentially ambiguous effect of a change in the volume of trade, a reduction in the dispersion of the prices of identical goods represents an unambiguous improvement in integration.

\footnotetext{
1 That is, Rose and his co-authors control for a wide variety of additional country specific variables, such as common language, colonial ties, contiguity, etc.
} 
Of course, using price data per se in empirical research is not new either. In an early study, Richardson (1978) finds that Canadian and United States prices are only weakly related. More recently, Rogers and Jenkins (1995) study Law of One Price (LOP) deviations, and are able to detect mean reversion in less than one-sixth of the 54 disaggregated products they study. Parsley and Wei (1996) find fairly rapid convergence of price differences within the United States, while Parsley and Wei (2001) find enormous market segmentation between the U.S. and Japan, though it is declining over time. Crucini et al. (2001), find sometimes large, (more than 50\%) deviations across European cities, but on average (across 1800 goods and services) these deviations are zero. Finally, using three years of the data used in this study, Rogers (2001) examines convergence to the law of one price within Europe. What is new in this paper is our adoption of price data to study the effect of the monetary regime and exchange rate stabilization on the progress of goods market integration. As far as we know, this paper is the first that uses this methodology on this topic.

In this paper, we make a conceptual distinction between institutional versus instrumental stabilization of the exchange rate. The former refers to reducing volatility through dollarization, adoption of a currency board, or via another common currency. The latter refers to reducing volatility through intervention in the foreign exchange market or via monetary policies, i.e., any arrangement other than institutional stabilization. Institutionalized stabilization implies a greater degree of commitment and a much lower probability of reversal in the future. By removing one more layer of uncertainty, it is conceivable that an institutionalized stabilization can provide a greater stimulus to goods market integration than merely reducing exchange rate volatility to zero via an instrumental stabilization. How big the extra stimulus is, must be determined by an empirical analysis.

We exploit both time series and cross-sectional variation available in the panel of local currency price data from the Economist Intelligence Unit. In particular, we study all (unique) bilateral 
price comparisons the data allow. Thus, in this study, we go beyond previous studies using two country, or at most intra-continental, price comparisons only.

Our main findings can be briefly summarized. First, reducing nominal exchange rate variability reduces relative price variability. Secondly, an economically stronger effect (by an order of magnitude) comes from participating in a hard peg - such as a currency union or explicitly abandoning the domestic currency and adopting a foreign currency. The largest institutional effects come through political and economic integration. Relative to the U.S. benchmark, European goods market integration still has further to go. Our results suggest that further political and economic integration can lead to substantial additional reductions in price dispersion.

The next section discusses the EIU data set in more detail, along with other data and sources we consult, and some basic patterns of the data. In section 3, we present the statistical evidence systematically, which is the heart of our analysis. Section 4 draws our conclusions.

\section{Data and Basic Patterns}

$\underline{\text { Data }}$

The primary data set we employ contains standardized price comparisons for over 160 goods and services for up to 122 cities compiled by the Economist Intelligence Unit. The data comes from the Worldwide Cost of Living Survey, and is designed for use by human resource managers in the design of compensation policies. The data set is described in more detail at http://eiu.enumerate.com/asp/wcol HelpWhatIsWCOL.asp. Many of the goods in the data set appear twice differing by the type of establishment where the price was recorded. That is for many goods in the data set there are two prices: one from a 'high-priced outlet' and one from a supermarket. Our focus in this study is on traded goods; and among traded goods we selected supermarket prices when there was a choice between two prices. 
Additionally, not all goods and cities are available in each time period. Since we are interested in both cross-sectional and time series variation, we dropped goods and cities with 'large' numbers of missing observations. Our rule was to drop goods where data was available for less than 16 (of the 122) cities. We generally wanted all goods to be available for the entire sample, and among the potential traded goods, hence we dropped goods with over $30 \%$ missing observations. Finally, we kept only one city per country (with the exception of the United States, which we use as a separate benchmark). The end result is a panel of 95 goods and 83 cities. Appendix Tables 1 and 2 list the goods and cities included.

In addition to the price data, we use data on tariff rates, from Table 6.6 of the World Bank publication World Development Indicators available on the World Bank web site. For each country the tariff data are available for two years - once in the early 1990s and once for the late 1990s. We use the first reported value in our bilateral tariff rate calculations for the years 1990-95. Similarly, we use the most recent value for the years 1996-2000. The precise variable definitions are discussed below. For this study we selected the columns "simple mean tariff” and “weighted mean tariff” (page 336-39). Additionally, we use monthly exchange rates and money supplies from the April 2001 IFS CD for all countries except Taiwan, where the data was taken from the CEIC data base provided by the Hong Kong Institute for Monetary Research.

\section{Percentage Price Differences: Some Examples}

As a starting point, we focus on the mean absolute percentage deviation. Let $P(i, k, t)$ be the U.S. dollar price of good $k$ in city $i$ at time $t$. For a given city pair $(i, j)$ and a given good $k$ at a time $t$, we define the common currency percentage price difference as:

$$
Q(i j, k, t)=\ln P(i, k, t)-\ln P(j, k, t) \text {. }
$$


As noted above, we study all bilateral price comparisons the data allow. There are 3403 city pairs $(=(83 \times 82) / 2)$ - each with 11 (annual) time periods. Thus, for each of the 95 prices, the vector of price deviations will contain $37,433(3403 \times 11)$ observations without missing values. Since for any given city-pair or time period $Q(i j, k, t)$ may be positive or negative, we first focus on absolute percentage price deviations.

As an illustration of the basic features of the data, Table 1 presents the percentage price dispersion (in absolute value) for three selected products among several city pairs. We make no claim that these are representative. They serve to only give a flavor of the data set and to presage some of the features we want to highlight.

The city pair Asuncion and Taipei is the farthest apart in our sample. The price difference for light bulbs and onions is also the biggest among the examples in Table 1 (though this need not be true for all the other products). A key issue that we will examine more formally is whether a reduction in exchange rate volatility would lead to a reduction in the segmentation of the goods market. Paris and Vienna have now belonged to a single currency union (euro) since the beginning of 1999. Comparing the price difference between the two cities in the pre-euro period versus the entire period, one observes a modest decline for the gap in the prices for light bulbs and onions. [Again, this need not be true for every product.] Among the examples in Table 1, the price difference between Chicago and Houston (two cities in the United States) is the smallest.

The evidence in Table 1 is suggestive. Exchange rate stabilization, particularly institutionalized stabilization, appears to stimulate goods market integration. Of course, Table 1 is anecdotal, since only two products are exhibited out of 95 goods in our sample. A more systematic approach is required, which is what we turn to next. 


\section{Statistical Analysis}

\section{$\underline{\text { Definition of price dispersion }}$}

A useful way to study goods market integration more generally is to study the cross sectional dispersion (across goods) of common currency price differentials for each city-pair and time period. An alternative strategy would be to study the cross sectional average. However, the logic of noarbitrage only imposes two inequality constraints on the prices of an identical good, $k$, in two different locations, $i$ and $j$. Intuitively, any particular realization of the common currency price differential, $Q(i j, k, t)=\ln P(i, k, t)-\ln P(j, k, t)$, can be either positive or negative without triggering arbitrage as long as $|Q(i j, k, t)|$ is less than the cost of arbitrage. In other words, the existence of arbitrage costs implies that $Q(i j, k, t)$ must fall within a range - not that it must equal, or even trend toward, zero. ${ }^{2}$ On the other hand, any reduction to barriers to trade (i.e., movements toward market integration) should reduce the no-arbitrage range. Hence, the strategy adopted here is to study a measure of the dispersion of $Q(i j, k, t)$ through time.

In particular, the variable we wish to explain is the standard deviation of $Q(i j, k, t)$, or $V(Q(i j, t))$. Prior to calculating variability we remove the time $t$ mean price difference (across citypairs), for each good separately. This filter removes the good specific effects from the cross-sectional variance calculation. Let $q(i j, k, t)$ be the residuals from that regression. We compute the standard deviation of $q$ (across goods, $k$ ) as our measure of variability. For robustness, we also examine the inter-quartile range between the $75^{\text {th }}$ and $25^{\text {th }}$ quartiles in the empirical distribution of all $k$ price differences for a given city-pair, as well as the standard deviation of absolute percentage price

\footnotetext{
${ }^{2}$ A more formal discussion is presented in O’Connell and Wei (2000).
} 
differences. The costs of arbitrage we focus on include distance, explicit trade barriers, and explicit institutional monetary arrangements.

Another important influence on price differentials not included in Table 1 is exchange rate variability more generally - i.e., as distinct from institutional arrangements limiting variability to be zero. Evidence presented by Rose (2000) that exchange rate variability has a large depressing effect on international trade implies that common currency price differences also vary with exchange rates. Hence, we wish to determine if these results generalize to international price differences.

Table 2 presents some summary data grouped by institutional arrangements. It is obvious that most of the bilateral city-pairs in the sample are not part of an institutional exchange rate arrangement - indeed only $4.5 \%$ are members. In columns 2 through 4, the average dispersion, distance and exchange rate variability are reported. Distance is calculated using the great circle formula using each city's latitude and longitude data obtained from the United Nation's web site http://www.un.org/Depts/unsd/demog/ctry.htm. Exchange rate variability is defined as the standard deviation of changes in the monthly bilateral exchange rate (between the city-pairs involved) during each year. In Table 2 we can detect a positive correlation between average variability of relative prices and distance. The correlation with exchange rate variability is less obvious since Hard Peg citypairs - with the second largest relative price variability, are on average quite far apart. Moreover, exchange rate variability is essentially zero for half of the classifications presented.

Figure 1 presents another, admittedly anecdotal, look at the data. In the figure, we compare two types of inter-city price dispersion: intra-national and international, for three city-pairs only. ${ }^{3}$ The city-pairs are (1) Chicago-Houston (1496 kilometers apart), (2) Chicago-Paris (6655 kilometers apart), and (3) Paris-Vienna (1034 kilometers apart). Dispersion is clearly lower for intra-national city-pairs

\footnotetext{
3 In the figure we continue to focus on $\mathrm{q}(\mathrm{ij}, \mathrm{t})$. That is, good specific effects have been removed.
} 
and a slight downward trend is apparent in this figure as well. As striking as this figure is, we do not yet know whether it is representative since only three of the more than three thousand city-pairs are included in the figure.

\section{$\underline{\text { Basic Regressions }}$}

We begin our formal investigation of factors influencing goods market integration by estimating equation 3 below.

$$
\begin{aligned}
V(q(i j, t))= & \beta_{1} \ln \left(\text { dist }_{i j}\right)+\beta_{1} \ln \left(\text { dist }_{i j}\right)^{2}+\beta_{3}\left(\text { xrvol }_{i j}\right)+\beta_{4} H P e g+\beta_{5} C F A+\beta_{6} U S+\beta_{7} \text { Euro } \\
& +\beta_{8} \text { Tariff }_{i j}+\text { city and time dummies }+\varepsilon_{i j, t}
\end{aligned}
$$

For convenience we measure the left hand side variable in percentage terms. In equation 3, HPeg, $C F A, U S$, Euro are dummy variables that take the value 1 if the observation for the dependent variable involves cities that are both part of the same institutional arrangement. We include both the $\log$ of the distance between cities $i$ and $j$, and the log distance squared in the regression to account for possible non-linearity in the relationship. Tariff is defined (initially) as the sum of the two average tariff rates in countries $i$ and $j$, unless the two cities are both in the same free trade area or customs union (such as within the United States, or within the European Union). In these cases the value for tariff is set equal to zero. In Section 5, we consider two alternative definitions of tariff for robustness.

Table 3 presents the benchmark regression results. According to column 1, dispersion of relative prices increases with distance, consistent with the interpretation that distance is a proxy for transportation cost, and the effect is nonlinear, i.e., distance increases dispersion, but at a declining rate. Increased exchange rate variability is also associated with increased relative price variability. In particular reducing monthly exchange rate variability from the sample average to zero reduces price dispersion by 0.263 percent $(=6.7 * 3.9 / 100)$. However, participating in a hard peg - such as a currency 
board or adopting another currency reduces price dispersion by 4.38 percent - an order of magnitude more than simply reducing exchange rate variability. This seems to indicate that a hard peg confers more than simply exchange rate stability. The point estimate on the CFA dummy is negative, however it is not statistically significant. The estimate for the 'Euro' dummy also implies a relatively large reduction in price dispersion - on the order of a hard peg. The coefficient on the 'Euro' dummy is in fact smaller than that on the "Hard Peg" dummy, though the difference is not statistically significant at the five percent level (the t-statistic from a formal test is 1.26). Perhaps this smaller effect for Euro is due to its relatively short history.

The strongest effect (statistically and economically) on price dispersion comes from being in the U.S., an effect we attribute to the higher levels of political and economic integration within the United States. The additional reduction in price dispersion associated with intra-U.S. cities is about three times larger than simply participating in a hard peg.

We can also express the economic effects of an institutional stabilization in terms of equivalent tariff reduction. According to the point estimates in the first column of Table 3, the effect of the euro on European goods market integration - in excess of reducing exchange rate volatility to zero - is equivalent to reducing the tariff rate in each country by 4 percentage points $[=3.42 /(0.44 * 2)]$. The average external tariff rate of the developed countries is about 4 percent. So these estimate suggest that the extra stimulus to goods market integration resulting from implementing a common currency (like the euro) is of the same order of magnitude as eliminating tariffs among the European countries under its common market program of the 1990s. In other words, the economic effect is not trivial.

As a comparison, for a random pair of countries, reducing exchange rate volatility from the world average $(0.067)$ to zero is equivalent to a tariff rate reduction of only 0.3 percentage points $[3.93 * 0.067 /(0.44 * 2)]$. Finally, the economic and political union of the United States has the biggest stimulus on goods market integration. Belonging to such a union provides a reduction in goods price 
dispersion (in excess of reducing exchange rate volatility to zero) that is similar to a reduction in tariffs by 13 percentage points $[=11.04 /(0.44 * 2)]$.

In sum, the evidence presented in Table 3 points to four conclusions. First, reducing nominal exchange rate variability reduces relative price variability. Secondly, an economically stronger effect (by an order of magnitude) comes from participating in a hard peg - such as a currency union or explicitly abandoning the domestic currency and adopting a foreign currency. The largest effects come through political and economic integration. We next turn to robustness and sensitivity analysis.

\section{Extensions and Robustness Checks}

We consider a host of extensions and sensitivity analyses. We first consider (a) some additional explanatory variables, and (b) some re-definitions of explanatory variables. Next we examine (c) different measures of the left-hand-side variable, namely, price dispersion. Finally, we consider (d) alternative specifications, including adding city-pair-specific random effects.

We begin with adding a measure of labor cost. This data was also obtained from the Economist Intelligence Unit as well. The first is the absolute value of the wage difference between the cities. According to Column 2 in Table 3, increasing the absolute percentage difference in wage rates between the two cities raises price dispersion, though the coefficient is not statistically significant. In order to investigate a possible non-linear relationship we entered the absolute wage difference squared as well. In the final column of the table we see that wage differences appear to be reflected in price dispersion, though the effect is not linear.

Next we turn to two different alternative definitions of the tariff variable in the regression. In Table 3 the tariff variable is the sum of the two cities trade-weighted average tariff rates. In column 1 of Table 4, we substitute instead the sum of the simple average tariff rates. This change has virtually no effect on the magnitudes or statistical significance of the other variables in the equation, and the 
coefficient on the new tariff definition is only slightly smaller than that on the weighted-average tariff. The coefficient on the CFA dummy remains statistically insignificant. In Columns 2 through 4, tariff is redefined as the maximum of the tariff rates between the two cities. The same qualitative conclusion applies.

Next, in column 3 we add the standard deviation of the wage difference - defined as the standard deviation of the absolute wage difference over the entire eleven-year period. According to the parameter estimate, higher variability is associated with greater price dispersion. In the final column, we eliminate extreme observations of the dependent variable and re-estimate. Doing this improves the fit of the equation substantially. The size of the "Euro" effect becomes slightly larger than that for the 'Hard peg', and the impact of exchange rate variability is smaller than before. However, none of the basic conclusions from Table 3 are changed.

To quantify whether price dispersion has been declining, we replace the fixed time effects with a trend dummy. These results are reported in Table 5. Looking across the columns in we see that the trend coefficient is indeed negative and statistically significant. Apparently there is a small downward trend in price dispersion at the rate of about one-percent per year. All other conclusions remain as before, with the exception that the Euro dummy is smaller (and indeed the point estimate is positive in Equations 2 and 3) than before.

In Table 6 we investigate the robustness of our results to an alternative definition of the lefthand-side variable. Specifically, we measure the dispersion in prices by the inter-quartile range of the percentage price difference between any two cities over the 95 goods, or the difference between the $75^{\text {th }}$ percentile and the $25^{\text {th }}$ percentile of the distribution of percentage price differences. We proceed as before, sequentially adding variables as we move through the columns in the table. Again, all the previous conclusions hold.

In Table 7, a third way to measure price dispersion is adopted - by using the standard 
deviation of the absolute differences in prices in percentage term. In Table 1 we presented some summary statistics on the average size of price differences across various groupings of city-pairs. We argued that since positive and negative differences would tend to cancel each other out, the simple average would misrepresent the true extent of price differences. ${ }^{4}$ Thus for comparability with Table 1 , we re-estimate the equations with the standard deviation of absolute percentage price differences as the dependent variable. Once again, our conclusions remain substantively unaffected by this redefinition of the dependent variable. The main exception is that the CFA dummy now becomes statistically significant, and the effect of tariffs appears somewhat smaller than before. The effects of joining the Euro or other Hard-peg are roughly comparable, and represent an additional reduction of price dispersion beyond reductions in nominal exchange rate variability alone. Finally, the effect of going still further, i.e., to complete political and economic union, remains the largest institutional effect limiting price dispersion.

Because exchange rate variability is potentially endogenous, we also implement an instrumental variable estimation. The monetary theory of exchange rate determination indicates that the relative money supplies of the two countries in question is an important determinant of their exchange rate. On the other hand, it seems unlikely that a country would change its money supply just to influence the dispersion of its tradable goods prices with another country. Therefore, on an ex ante basis, changes in the relative money supply could be a good instrument for changes in the exchange rate. In concrete terms, we first instrument monthly exchange rates with relative narrow money supplies. We then compute variability as the standard deviation of the changes in the monthly instrumentedexchange rate (between the city-pairs involved) during each year. Table 8 presents these results. Virtually the only change in this table from the previous results is that the coefficients on exchange

\footnotetext{
${ }^{4}$ In principle, given that our focus is on the dispersion in prices, the tendency for positive and negative values to cancel should not be a concern (since dispersion is measured around the mean).
} 
rate variability have risen. According to Equation 4, (from the regression omitting extreme observations on the dependent variable), reducing exchange rate variability from the sample average to zero reduces price dispersion by 0.958 percent - an amount three times larger than reported in Table 3. Even with this larger effect of reducing exchange rate variability, all other conclusions - including the relative ranking of effects - remain as previously stated. In another iteration of instrumental variable estimation, we included a lagged value of the exchange rate in the instrument set. Though we do not report these results here to save space, our conclusions are robust to this permutation as well.

To consider possible non-linear effects of exchange rate volatility on price dispersion, we include the square of exchange rate variability as an additional regressor. These results are reported in Table 9. The evidence suggests that the effect of exchange rate volatility on price dispersion is positive but concave: higher exchange rate volatility is associated with a greater price dispersion, but the incremental effect gets smaller as volatility increases.

So far, we use city fixed effects and year fixed effects to capture factors that may affect the dispersion in prices between cities that are not otherwise in the list of regressors. In Table 10, we add city-pair specific random effects to the regressions, in addition to the city and year fixed effects. These results are broadly similar to the previous tables. The primary exception is in the estimate for the Euro. It is generally much smaller than that for the Hard Peg dummy, and the Euro dummy lacks statistical significance in all equations. The coefficient on Hard Peg is statistically significant in three out of four specifications. The U.S. dummy remains highly statistically significant and economically dominates the other institutional arrangement effects.

In Table 11, we consider some alternative institutional classifications and controls for language ties, high inflation episodes, and trade blocs. The language dummy takes the value 1 if the city pair shares a common language (either official or primary business language), and zero otherwise. The data was taken from the CLA World Factbook (http://www.cia.gov/cia/publications/factbook/ 
indexgeo.html). According to the estimates in Table 11, sharing a common language (or a common colonial past) - and all that that implies - reduces price dispersion. Among the Hard Peg arrangements that are studied in the sample, two of the country pairs - the Panama-US pair and the Belgium-Luxembourg pair - stand out by their long history. In the first column of Table 11 we replace our Hard Peg dummy with a separate dummy for long-term pegs (Panama-US, and BelgiumLuxembourg), and Currency Boards (Hong Kong-US, and Argentina-US). Both these new dummies are statistically significant. The point estimate on long-term currency unions is roughly twice that for (more recent) Currency Board. As we include more regressors (in columns 2-3) the estimate of reduction in price dispersion attributable to Long-term pegs declines a bit (from - 7.7 in column 1 to 5.5 percent in column 6), but the distinction between Long-term pegs and Currency Boards remains; the effect of long-term pegs on price dispersion is always above that for more recent currency boards.

In Column 2 we add a dummy for hyper-inflationary episodes/countries. The episodes were: Argentina (1992), Peru (1991), Mexico (1993), Uruguay (1993), Brazil (1993-4), and Poland (1995). This improves the fit of the regression substantially - there is a dramatic rise in the adjusted R-square from 0.23 to 0.73 . On the other hand, the coefficients on all other important regressors are virtually unchanged.

We have been focusing on the differential effects of institutional versus instrumental stabilization of exchange rate volatility on the goods market integration. As an analogy, we can also examine whether formation of a trade bloc could have a different effect on goods market integration than a mere reduction in tariff rates. The idea is that a trade bloc implies a greater degree of commitment to maintaining low tariff (and non-tariff) barriers to trade on imports from member countries, i.e., reductions in tariffs are less likely to be reversed. To investigate this possibility, in the final column of Table 11, we add controls for all the prominent trade blocs in Europe and in the Americas. These are: the European Union (EU), the European Free Trade Association (EFTA), the 
Central European Free Trade Area (CEFTA), the North American Free Trade Agreement (NAFTA), and Mercado Comun del Sur (MERCOSUR).

The coefficients on all of the trade blocs are negative, consistent with the interpretation that an institutionalized reduction in trade barriers (through the formation of a trade bloc) would promote greater integration in the goods market than merely reducing trade barriers through a unilateral trade liberalization. The coefficients on four of the five trade blocs (i.e., except CEFTA) are statistically significant. Other conclusions are similar as before. Specifically, a reduction in exchange rate volatility promotes goods market integration in the form of a reduction in the range of price dispersion. A currency board arrangement promotes goods market integration to an extent much greater than merely reducing the exchange rate volatility to zero. Long-term currency unions such as the Panama's adoption of the U.S. dollar or the Belgium-Luxembourg currency union offer an even greater stimulus to goods market integration than a currency board. The degree of market integration associated with a long-term, political and economic union as the United States is the highest of all - i.e., the dispersion of prices for identical goods is the smallest. Another interesting observation is that, once one takes into account the fact that the European Union confers a high degree of goods market integration, the launching of Euro so far has not generated a noticeable further integration. Time could change this.

So far, we have not included city-pair fixed effects in the regressions (though city and year fixed effects are included). This is because many variables of central interest to us, such as most of the currency arrangements, have virtually no time variation in our sample. The inclusion of the countrypair fixed effects would impede our ability to estimate these parameters of interest. However, if we restrict our interest to estimating the effect of exchange rate volatility, we could potentially include them. There are altogether 3403 city pairs $(=83 X 82 / 2)$ in the sample. In Table 12, we include these city-pair fixed effects together with the 11 year dummies. The coefficient on the exchange rate variable is still positive and statistically significant at the one percent level. On the other hand, the size 
of the point estimates (between 1.3 and 3.5) is somewhat smaller than in the previous tables.

A surprise in Column 3 is that a greater absolute wage difference is associated with lower price dispersion. However, the estimates for nominal exchange rate variability, high inflation episodes, and tariffs are unaffected by these additional wage variables. In the final column, we remove the outliers (the top and bottom $1 \%$ of the observations in terms of the range of price dispersion) on the dependent variable. In this specification, the sign on the wage variables reverts to that reported in earlier tables. Overall, Table 12 confirms one of our main findings - namely, reducing nominal exchange rate variability lowers price dispersion. This effect is not driven by any omitted, city-pairspecific factor.

\section{Conclusions}

This paper empirically examines the effect of exchange rate and monetary arrangement on the integration of goods markets. The methodological innovation is to use the range of price dispersion of identical goods rather than volume of trade as a measure of market integration, and to use a 3dimensional panel of 95 very disaggregated prices (e.g., light bulbs) from 83 cities from around the world to construct the price dispersion measure.

We compare observed prices of these products for 3403 city-pairs for the eleven-year period 1990-2000. We find that goods market integration is increasing over time and is inversely related to distance, exchange rate variability, and tariff barriers. Economically however, the impact of adopting a hard peg (currency board or currency union) is much larger than merely reducing exchange rate volatility to zero. Long-term currency union has a greater impact than more recent currency boards. However, relative to the U.S. benchmark, all existing currency boards or unions such as Euro still have further to go to improve the integration of their goods market.

We have subjected our basic results to numerous sensitivity tests and found them 
fundamentally robust to different definitions of the dependent and independent variables, different specifications, the exclusion of extreme values, and to different estimation methodologies. In the future, a useful work would be to combine the price-based approach in this paper with the quantitybased approach in the literature. 
Table 1: Percentage Price Deviations in Absolute Value (averaged over all years)

Asuncion-Taipei

Light Bulbs

65.4

Onions

Paris-Vienna (1990-1998, pre-euro)

Light Bulbs

Onions

Paris-Vienna

Light Bulbs

11.4

Onions

40.1

Chicago-Houston

Light Bulbs

8.9

Onions

42.7 
Table 2: Dispersion and its Determinants: Averages across city pairs and time

\begin{tabular}{|c|c|c|c|c|c|}
\hline & Observations & $V(q(i j, t))^{4}$ & Distance & $V(s(i j, t))^{5}$ & Tarriff ${ }^{6}$ \\
\hline All City Pairs & 36531 & 6.38 & 8215 & 0.67 & 22.3 \\
\hline Hard Peg City Pairs ${ }^{1}$ & 454 & 5.76 & 8602 & 0.01 & 9.8 \\
\hline US Only City Pairs & 975 & 3.78 & 2681 & 0.00 & 0.0 \\
\hline$C F A$ City Pairs ${ }^{2}$ & 110 & 6.29 & 3139 & 0.27 & 41.9 \\
\hline Euro City Pairs ${ }^{3}$ & 110 & 4.19 & 1273 & 0.00 & 0.0 \\
\hline Euro City Pairs (pre-Euro) & 495 & 4.37 & 1273 & 0.13 & 0.0 \\
\hline
\end{tabular}

${ }^{1}$ Hard Peg city-pairs are defined as city-pairs involving price comparisons between two cities maintaining a peg to the same currency. The Hard Peg classification includes three groups of bilateral pairs: (a) pairs that involve Buenos Aires (post 1992), Hong Kong, and Panama City, (b) bilateral pairs between those cities in (a) and U.S. cities, and (c) Brussels and Luxembourg.

${ }^{2}$ CFA city-pairs are defined as city-pairs involving price comparisons between two of the following cities: Abidjan, Dakar, Douala, Libreville, and Paris.

${ }^{3}$ Euro city-pairs are defined as city-pairs involving price comparisons between two of the following cities (post 1998): Amsterdam, Berlin, Brussels, Dublin, Helsinki, Lisbon, Luxembourg, Madrid, Paris, Rome, and Vienna.

${ }^{4}$ This column reports the average across relevant city-pair groupings (and time) of the dispersion of (demeaned) percentage price differences.

${ }^{5}$ This column reports the average across relevant city-pair groupings (and time) of the variability of (defined as changes in log monthly) bilateral nominal exchange rates.

${ }^{6}$ Tariff is defined as the sum of the two individual tariff rates in countries $i$ and $j$, unless the two cities are both in the United States, or they are both in the European Union. In these cases the value for tariff is set equal to zero. 
Table 3: Benchmark Regression Results

\begin{tabular}{|c|c|c|c|}
\hline Log Distance & $\begin{array}{c}\text { Equation } 1 \\
12.67 \\
(2.13)\end{array}$ & $\begin{array}{c}\text { Equation } 2 \\
13.20 \\
(2.30)\end{array}$ & $\begin{array}{c}\text { Equation } 3 \\
12.16 \\
(2.29)\end{array}$ \\
\hline Log Distance Squared & $\begin{array}{l}-0.60 \\
(0.14)\end{array}$ & $\begin{array}{l}-0.63 \\
(0.15)\end{array}$ & $\begin{array}{l}-0.57 \\
(0.15)\end{array}$ \\
\hline $\begin{array}{l}\text { Nominal Exchange } \\
\text { Rate Variability }\end{array}$ & $\begin{array}{l}3.93 \\
(1.14)\end{array}$ & $\begin{array}{l}3.62 \\
(1.16)\end{array}$ & $\begin{array}{l}5.42 \\
(1.00)\end{array}$ \\
\hline Hard Peg & $\begin{array}{l}-4.38 \\
(0.65)\end{array}$ & $\begin{array}{l}-3.25 \\
(0.70)\end{array}$ & $\begin{array}{l}-2.48 \\
(0.67)\end{array}$ \\
\hline CFA & $\begin{array}{l}-1.49 \\
(1.48)\end{array}$ & $\begin{array}{l}-1.02 \\
(1.56)\end{array}$ & $\begin{array}{l}-0.90 \\
(1.52)\end{array}$ \\
\hline U.S. & $\begin{array}{l}-11.04 \\
(.44)\end{array}$ & $\begin{array}{l}-10.15 \\
(0.48)\end{array}$ & $\begin{array}{l}-9.55 \\
(0.47)\end{array}$ \\
\hline Euro & $\begin{array}{l}-3.42 \\
(0.56)\end{array}$ & $\begin{array}{l}-2.47 \\
(0.59)\end{array}$ & $\begin{array}{l}-1.65 \\
(0.55)\end{array}$ \\
\hline Weighted Avg. Tariff & $\begin{array}{l}0.44 \\
(0.01)\end{array}$ & $\begin{array}{l}0.41 \\
(0.01)\end{array}$ & $\begin{array}{l}0.43 \\
(0.01)\end{array}$ \\
\hline $\begin{array}{l}\text { Absolute Wage } \\
\text { Difference }\end{array}$ & & $\begin{array}{l}0.21 \\
(0.14)\end{array}$ & $\begin{array}{l}3.02 \\
(0.38)\end{array}$ \\
\hline $\begin{array}{l}\text { Absolute Wage } \\
\text { Difference Squared }\end{array}$ & & & $\begin{array}{l}-0.25 \\
(0.03)\end{array}$ \\
\hline Year dummies? & yes & yes & yes \\
\hline City dummies? & yes & yes & yes \\
\hline $\begin{array}{l}\text { Adjusted } \mathrm{R}^{2} \\
\text { Number of Observations }\end{array}$ & $\begin{array}{l}.23 \\
27406\end{array}$ & $\begin{array}{l}.22 \\
21863\end{array}$ & $\begin{array}{l}.23 \\
21863\end{array}$ \\
\hline
\end{tabular}

Robust standard errors are in parenthesis. All equations include city and time fixed effects. 


\begin{tabular}{|c|c|c|c|c|}
\hline Log Distance & $\begin{array}{c}\text { Equation } 1 \\
13.12 \\
(2.30)\end{array}$ & $\begin{array}{c}\text { Equation } 2 \\
13.54 \\
(2.30)\end{array}$ & $\begin{array}{c}\text { Equation } 3 \\
13.63 \\
(2.28)\end{array}$ & $\begin{array}{c}\text { Equation } 4 \\
10.91 \\
(1.01)\end{array}$ \\
\hline Log Distance Squared & $\begin{array}{l}-0.64 \\
(0.15)\end{array}$ & $\begin{array}{l}-0.66 \\
(0.15)\end{array}$ & $\begin{array}{l}-0.68 \\
(0.15)\end{array}$ & $\begin{array}{l}-0.52 \\
(0.06)\end{array}$ \\
\hline $\begin{array}{l}\text { Nominal Exchange } \\
\text { Rate Variability }\end{array}$ & $\begin{array}{l}5.27 \\
(1.00)\end{array}$ & $\begin{array}{l}5.18 \\
(1.00)\end{array}$ & $\begin{array}{l}5.43 \\
(1.01)\end{array}$ & $\begin{array}{l}2.37 \\
(0.29)\end{array}$ \\
\hline Hard Peg & $\begin{array}{l}-2.80 \\
(0.68)\end{array}$ & $\begin{array}{l}-3.28 \\
(0.69)\end{array}$ & $\begin{array}{l}-3.59 \\
(0.67)\end{array}$ & $\begin{array}{l}-2.42 \\
(0.42)\end{array}$ \\
\hline CFA & $\begin{array}{l}-0.54 \\
(1.37)\end{array}$ & $\begin{array}{l}0.53 \\
(1.46)\end{array}$ & $\begin{array}{l}1.18 \\
(1.45)\end{array}$ & $\begin{array}{l}1.38 \\
(1.20)\end{array}$ \\
\hline U.S. & $\begin{array}{l}-9.61 \\
(0.47)\end{array}$ & $\begin{array}{l}-10.55 \\
(0.47)\end{array}$ & $\begin{array}{l}-10.06 \\
(0.46)\end{array}$ & $\begin{array}{l}-7.74 \\
(0.27)\end{array}$ \\
\hline Euro & $\begin{array}{l}-1.90 \\
(0.55)\end{array}$ & $\begin{array}{l}-2.35 \\
(0.54)\end{array}$ & $\begin{array}{l}-1.51 \\
(0.56)\end{array}$ & $\begin{array}{l}-3.74 \\
(0.42)\end{array}$ \\
\hline $\begin{array}{l}\text { Absolute Wage } \\
\text { Difference }\end{array}$ & $\begin{array}{l}3.02 \\
(0.38)\end{array}$ & $\begin{array}{l}2.88 \\
(0.38)\end{array}$ & $\begin{array}{l}2.63 \\
(0.38)\end{array}$ & $\begin{array}{l}3.26 \\
(0.11)\end{array}$ \\
\hline $\begin{array}{l}\text { Absolute Wage } \\
\text { Difference Squared }\end{array}$ & $\begin{array}{l}-0.26 \\
(0.03)\end{array}$ & $\begin{array}{l}-0.24 \\
(0.03)\end{array}$ & $\begin{array}{l}-0.30 \\
(0.04)\end{array}$ & $\begin{array}{l}-0.25 \\
(0.01)\end{array}$ \\
\hline Equal Weighted Tariff & $\begin{array}{l}0.35 \\
(0.01)\end{array}$ & & & \\
\hline Maximum Tariff & & $\begin{array}{l}0.39 \\
(0.01)\end{array}$ & $\begin{array}{l}0.37 \\
(0.01)\end{array}$ & $\begin{array}{l}0.35 \\
(0.01)\end{array}$ \\
\hline $\begin{array}{l}\text { Standard Deviation of } \\
\text { Wage Difference }\end{array}$ & & & $\begin{array}{l}3.00 \\
(0.38)\end{array}$ & $\begin{array}{l}0.65 \\
(0.06)\end{array}$ \\
\hline $\begin{array}{l}\text { Year dummies? } \\
\text { City dummies? }\end{array}$ & $\begin{array}{l}\text { yes } \\
\text { yes }\end{array}$ & $\begin{array}{l}\text { yes } \\
\text { yes }\end{array}$ & $\begin{array}{l}\text { yes } \\
\text { yes }\end{array}$ & $\begin{array}{l}\text { yes } \\
\text { yes }\end{array}$ \\
\hline $\begin{array}{l}\text { Adjusted } \mathrm{R}^{2} \\
\text { Number of Observations }\end{array}$ & $\begin{array}{c}.23 \\
21863\end{array}$ & $\begin{array}{c}.23 \\
21863\end{array}$ & $\begin{array}{c}.24 \\
21842\end{array}$ & $\begin{array}{c}.58 \\
20945\end{array}$ \\
\hline
\end{tabular}


Table 5: Time Trend

\begin{tabular}{|c|c|c|c|c|}
\hline Log Distance & $\begin{array}{c}\text { Equation } 1 \\
12.73 \\
(2.14)\end{array}$ & $\begin{array}{c}\text { Equation } 2 \\
12.21 \\
(2.31)\end{array}$ & $\begin{array}{c}\text { Equation } 3 \\
12.53 \\
(2.30)\end{array}$ & $\begin{array}{c}\text { Equation } 4 \\
10.21 \\
(0.99)\end{array}$ \\
\hline Log Distance Squared & $\begin{array}{l}-0.60 \\
(0.14)\end{array}$ & $\begin{array}{l}-0.58 \\
(0.15)\end{array}$ & $\begin{array}{l}-0.60 \\
(0.15)\end{array}$ & $\begin{array}{l}-0.46 \\
(0.06)\end{array}$ \\
\hline $\begin{array}{l}\text { Nominal Exchange } \\
\text { Rate Variability }\end{array}$ & $\begin{array}{l}5.69 \\
(1.04)\end{array}$ & $\begin{array}{l}6.98 \\
(0.93)\end{array}$ & $\begin{array}{l}7.19 \\
(0.94)\end{array}$ & $\begin{array}{l}3.40 \\
(0.28)\end{array}$ \\
\hline Hard Peg & $\begin{array}{l}-4.78 \\
(0.66)\end{array}$ & $\begin{array}{l}-2.78 \\
(0.67)\end{array}$ & $\begin{array}{l}-3.12 \\
(0.67)\end{array}$ & $\begin{array}{l}-1.84 \\
(0.43)\end{array}$ \\
\hline CFA & $\begin{array}{l}-1.38 \\
(1.40)\end{array}$ & $\begin{array}{l}-0.72 \\
(1.44)\end{array}$ & $\begin{array}{l}0.00 \\
(1.40)\end{array}$ & $\begin{array}{l}0.31 \\
(1.26)\end{array}$ \\
\hline U.S. & $\begin{array}{l}-11.07 \\
(0.43)\end{array}$ & $\begin{array}{l}-9.53 \\
(0.46)\end{array}$ & $\begin{array}{l}-9.30 \\
(0.46)\end{array}$ & $\begin{array}{l}-7.64 \\
(0.25)\end{array}$ \\
\hline Euro & $\begin{array}{l}-1.14 \\
(0.57)\end{array}$ & $\begin{array}{l}0.60 \\
(0.58)\end{array}$ & $\begin{array}{l}1.36 \\
(0.62)\end{array}$ & $\begin{array}{l}-1.21 \\
(0.43)\end{array}$ \\
\hline Weighted Avg. Tariff & $\begin{array}{l}0.43 \\
(0.01)\end{array}$ & $\begin{array}{l}0.42 \\
(0.01)\end{array}$ & $\begin{array}{l}0.39 \\
(0.01)\end{array}$ & $\begin{array}{l}0.38 \\
(0.01)\end{array}$ \\
\hline Trend & $\begin{array}{l}-1.08 \\
(0.05)\end{array}$ & $\begin{array}{l}-1.03 \\
(0.07)\end{array}$ & $\begin{array}{l}-1.15 \\
(0.07)\end{array}$ & $\begin{array}{l}-0.65 \\
(0.02)\end{array}$ \\
\hline $\begin{array}{l}\text { Absolute Wage } \\
\text { Difference }\end{array}$ & & $\begin{array}{l}3.54 \\
(0.38)\end{array}$ & $\begin{array}{l}3.32 \\
(0.38)\end{array}$ & $\begin{array}{l}3.78 \\
(0.12)\end{array}$ \\
\hline $\begin{array}{l}\text { Absolute Wage } \\
\text { Difference Squared }\end{array}$ & & $\begin{array}{l}-0.28 \\
(0.04)\end{array}$ & $\begin{array}{l}-0.33 \\
(0.04)\end{array}$ & $\begin{array}{l}-0.27 \\
(0.01)\end{array}$ \\
\hline $\begin{array}{l}\text { Standard Deviation of } \\
\text { Wage Difference }\end{array}$ & & & $\begin{array}{l}2.59 \\
(0.38)\end{array}$ & $\begin{array}{l}0.25 \\
(0.06)\end{array}$ \\
\hline $\begin{array}{l}\text { Adjusted } \mathrm{R}^{2} \\
\text { Number of Observations }\end{array}$ & $\begin{array}{c}.21 \\
27406\end{array}$ & $\begin{array}{l}.21 \\
21863\end{array}$ & $\begin{array}{c}.22 \\
21863\end{array}$ & $\begin{array}{c}.59 \\
21398\end{array}$ \\
\hline
\end{tabular}


Table 6: Measuring Price Dispersion by the Inter-quartile Range of $q$

\begin{tabular}{|c|c|c|c|c|}
\hline Log Distance & $\begin{array}{c}\text { Equation } 1 \\
17.82 \\
(2.21)\end{array}$ & $\begin{array}{c}\text { Equation } 2 \\
14.91 \\
(2.32)\end{array}$ & $\begin{array}{c}\text { Equation } 3 \\
14.99 \\
(2.31)\end{array}$ & $\begin{array}{c}\text { Equation } 4 \\
12.42 \\
(1.55)\end{array}$ \\
\hline Log Distance Squared & $\begin{array}{l}-0.80 \\
(0.14)\end{array}$ & $\begin{array}{l}-0.64 \\
(0.15)\end{array}$ & $\begin{array}{l}-0.64 \\
(0.15)\end{array}$ & $\begin{array}{l}-0.49 \\
(0.10)\end{array}$ \\
\hline $\begin{array}{l}\text { Nominal Exchange } \\
\text { Rate Variability }\end{array}$ & $\begin{array}{l}4.54 \\
(0.84)\end{array}$ & $\begin{array}{l}5.50 \\
(0.82)\end{array}$ & $\begin{array}{l}5.51 \\
(0.83)\end{array}$ & $\begin{array}{l}4.83 \\
(0.54)\end{array}$ \\
\hline Hard Peg & $\begin{array}{l}-6.30 \\
(0.87)\end{array}$ & $\begin{array}{l}-3.71 \\
(0.87)\end{array}$ & $\begin{array}{l}-3.80 \\
(0.87)\end{array}$ & $\begin{array}{l}-2.60 \\
(0.75)\end{array}$ \\
\hline CFA & $\begin{array}{l}2.17 \\
(1.91)\end{array}$ & $\begin{array}{l}2.68 \\
(1.96)\end{array}$ & $\begin{array}{l}2.85 \\
(1.96)\end{array}$ & $\begin{array}{l}3.13 \\
(1.82)\end{array}$ \\
\hline U.S. & $\begin{array}{l}-18.19 \\
(0.51)\end{array}$ & $\begin{array}{l}-16.58 \\
(0.52)\end{array}$ & $\begin{array}{l}-16.55 \\
(0.53)\end{array}$ & $\begin{array}{l}-14.43 \\
(0.40)\end{array}$ \\
\hline Euro & $\begin{array}{l}-7.02 \\
(0.78)\end{array}$ & $\begin{array}{l}-4.54 \\
(0.78)\end{array}$ & $\begin{array}{l}-4.44 \\
(0.79)\end{array}$ & $\begin{array}{l}-4.92 \\
(0.72)\end{array}$ \\
\hline Weighted Avg. Tariff & $\begin{array}{l}0.44 \\
(0.01)\end{array}$ & $\begin{array}{l}0.45 \\
(0.01)\end{array}$ & $\begin{array}{l}0.44 \\
(0.01)\end{array}$ & $\begin{array}{l}0.46 \\
(0.01)\end{array}$ \\
\hline $\begin{array}{l}\text { Absolute Wage } \\
\text { Difference }\end{array}$ & & $\begin{array}{l}4.88 \\
(0.33)\end{array}$ & $\begin{array}{l}4.83 \\
(0.33)\end{array}$ & $\begin{array}{l}5.06 \\
(0.19)\end{array}$ \\
\hline $\begin{array}{l}\text { Absolute Wage } \\
\text { Difference Squared }\end{array}$ & & $\begin{array}{l}-0.37 \\
(0.03)\end{array}$ & $\begin{array}{l}-0.38 \\
(0.03)\end{array}$ & $\begin{array}{l}-0.37 \\
(0.02)\end{array}$ \\
\hline $\begin{array}{l}\text { Standard Deviation of } \\
\text { Wage Difference }\end{array}$ & & & $\begin{array}{l}0.55 \\
(0.33)\end{array}$ & $\begin{array}{l}0.34 \\
(0.10)\end{array}$ \\
\hline $\begin{array}{l}\text { Year dummies? } \\
\text { City dummies? }\end{array}$ & $\begin{array}{l}\text { yes } \\
\text { yes }\end{array}$ & $\begin{array}{l}\text { yes } \\
\text { yes }\end{array}$ & $\begin{array}{l}\text { yes } \\
\text { yes }\end{array}$ & $\begin{array}{l}\text { yes } \\
\text { yes }\end{array}$ \\
\hline $\begin{array}{l}\text { Adjusted } \mathrm{R}^{2} \\
\text { Number of Observations }\end{array}$ & $\begin{array}{c}.30 \\
27551\end{array}$ & $\begin{array}{l}.33 \\
21928\end{array}$ & $\begin{array}{c}.33 \\
21928\end{array}$ & $\begin{array}{c}.52 \\
21503\end{array}$ \\
\hline
\end{tabular}


Table 7: Measuring Price Dispersion by Standard Deviation of $|\mathrm{q}|$

\begin{tabular}{|c|c|c|c|c|}
\hline Log Distance & $\begin{array}{l}\text { Equation } 1 \\
7.66 \\
(2.01)\end{array}$ & $\begin{array}{l}\text { Equation } 2 \\
\quad 6.29 \\
(2.07)\end{array}$ & $\begin{array}{l}\text { Equation } 3 \\
\quad 6.55 \\
(2.05)\end{array}$ & $\begin{array}{c}\text { Equation } 4 \\
4.83 \\
(0.79)\end{array}$ \\
\hline Log Distance Squared & $\begin{array}{l}-0.39 \\
(0.13)\end{array}$ & $\begin{array}{l}-0.32 \\
(0.14)\end{array}$ & $\begin{array}{l}-0.34 \\
(0.13)\end{array}$ & $\begin{array}{l}-0.23 \\
(0.05)\end{array}$ \\
\hline $\begin{array}{l}\text { Nominal Exchange } \\
\text { Rate Variability }\end{array}$ & $\begin{array}{l}7.03 \\
(1.20)\end{array}$ & $\begin{array}{l}3.80 \\
(1.01)\end{array}$ & $\begin{array}{l}4.00 \\
(1.01)\end{array}$ & $\begin{array}{l}1.12 \\
(0.26)\end{array}$ \\
\hline Hard Peg & $\begin{array}{l}-6.76 \\
(0.66)\end{array}$ & $\begin{array}{l}-3.48 \\
(0.60)\end{array}$ & $\begin{array}{l}-3.80 \\
(0.61)\end{array}$ & $\begin{array}{l}-2.81 \\
(0.31)\end{array}$ \\
\hline CFA & $\begin{array}{l}-5.76 \\
(1.23)\end{array}$ & $\begin{array}{l}-4.10 \\
(1.08)\end{array}$ & $\begin{array}{l}-3.51 \\
(1.07)\end{array}$ & $\begin{array}{l}-3.10 \\
(0.83)\end{array}$ \\
\hline U.S. & $\begin{array}{l}-8.50 \\
(0.41)\end{array}$ & $\begin{array}{l}-6.56 \\
(0.42)\end{array}$ & $\begin{array}{l}-6.38 \\
(0.42)\end{array}$ & $\begin{array}{l}-5.52 \\
(0.19)\end{array}$ \\
\hline Euro & $\begin{array}{l}-1.07 \\
(0.48)\end{array}$ & $\begin{array}{l}-0.69 \\
(0.43)\end{array}$ & $\begin{array}{l}-0.19 \\
(0.45)\end{array}$ & $\begin{array}{l}-2.06 \\
(0.32)\end{array}$ \\
\hline Weighted Avg. Tariff & $\begin{array}{l}0.30 \\
(0.01)\end{array}$ & $\begin{array}{l}0.25 \\
(0.01)\end{array}$ & $\begin{array}{l}0.23 \\
(0.01)\end{array}$ & $\begin{array}{l}0.21 \\
(0.01)\end{array}$ \\
\hline $\begin{array}{l}\text { Absolute Wage } \\
\text { Difference }\end{array}$ & & $\begin{array}{l}6.66 \\
(0.35)\end{array}$ & $\begin{array}{l}6.47 \\
(0.36)\end{array}$ & $\begin{array}{l}7.22 \\
(0.11)\end{array}$ \\
\hline $\begin{array}{l}\text { Absolute Wage } \\
\text { Difference Squared }\end{array}$ & & $\begin{array}{l}-0.36 \\
(0.03)\end{array}$ & $\begin{array}{l}-0.40 \\
(0.04)\end{array}$ & $\begin{array}{l}-0.37 \\
(0.01)\end{array}$ \\
\hline $\begin{array}{l}\text { Standard Deviation of } \\
\text { Wage Difference }\end{array}$ & & & $\begin{array}{l}2.11 \\
(0.35)\end{array}$ & $\begin{array}{l}0.06 \\
(0.05)\end{array}$ \\
\hline $\begin{array}{l}\text { Year dummies? } \\
\text { City dummies? } \\
\text { Adjusted } \mathrm{R}^{2} \\
\text { Number of Observations }\end{array}$ & $\begin{array}{l}\text { yes } \\
\text { yes } \\
.20 \\
27406\end{array}$ & $\begin{array}{l}\text { yes } \\
\text { yes } \\
.25 \\
21863\end{array}$ & $\begin{array}{l}\text { yes } \\
\text { yes } \\
.25 \\
21863\end{array}$ & $\begin{array}{c}\text { yes } \\
\text { yes } \\
.68 \\
21393\end{array}$ \\
\hline
\end{tabular}


Table 8: Instrumental Variable Estimation

\begin{tabular}{|c|c|c|c|c|}
\hline Log Distance & $\begin{array}{c}\text { Equation } 1 \\
12.87 \\
(2.14)\end{array}$ & $\begin{array}{c}\text { Equation } 2 \\
12.49 \\
(2.31)\end{array}$ & $\begin{array}{c}\text { Equation } 3 \\
13.03 \\
(2.29)\end{array}$ & $\begin{array}{c}\text { Equation } 4 \\
10.27 \\
(0.98)\end{array}$ \\
\hline Log Distance Squared & $\begin{array}{l}-0.61 \\
(0.14)\end{array}$ & $\begin{array}{l}-0.59 \\
(0.15)\end{array}$ & $\begin{array}{l}-0.63 \\
(0.15)\end{array}$ & $\begin{array}{l}-0.46 \\
(0.06)\end{array}$ \\
\hline $\begin{array}{l}\text { Nominal Exchange } \\
\text { Rate Variability }\end{array}$ & $\begin{array}{l}7.97 \\
(1.38)\end{array}$ & $\begin{array}{l}9.10 \\
(1.51)\end{array}$ & $\begin{array}{l}-3.74 \\
(2.80)\end{array}$ & $\begin{array}{l}14.31 \\
(1.30)\end{array}$ \\
\hline Hard Peg & $\begin{array}{l}-4.48 \\
(0.64)\end{array}$ & $\begin{array}{l}-2.63 \\
(0.67)\end{array}$ & $\begin{array}{l}-3.30 \\
(0.66)\end{array}$ & $\begin{array}{l}-1.61 \\
(0.42)\end{array}$ \\
\hline CFA & $\begin{array}{l}-1.41 \\
(1.49)\end{array}$ & $\begin{array}{l}-0.79 \\
(1.53)\end{array}$ & $\begin{array}{l}-0.39 \\
(1.50)\end{array}$ & $\begin{array}{l}0.50 \\
(1.27)\end{array}$ \\
\hline U.S. & $\begin{array}{l}-11.03 \\
(0.44)\end{array}$ & $\begin{array}{l}-9.65 \\
(0.48)\end{array}$ & $\begin{array}{l}-9.68 \\
(0.47)\end{array}$ & $\begin{array}{l}-7.61 \\
(0.26)\end{array}$ \\
\hline Euro & $\begin{array}{l}-3.74 \\
(0.53)\end{array}$ & $\begin{array}{l}-2.30 \\
(0.53)\end{array}$ & $\begin{array}{l}-2.26 \\
(0.53)\end{array}$ & $\begin{array}{l}-3.22 \\
(0.45)\end{array}$ \\
\hline Weighted Avg. Tariff & $\begin{array}{l}0.44 \\
(0.01)\end{array}$ & $\begin{array}{l}0.43 \\
(0.01)\end{array}$ & $\begin{array}{l}0.40 \\
(0.01)\end{array}$ & $\begin{array}{l}0.38 \\
(0.01)\end{array}$ \\
\hline $\begin{array}{l}\text { Absolute Wage } \\
\text { Difference }\end{array}$ & & $\begin{array}{l}2.92 \\
(0.39)\end{array}$ & $\begin{array}{l}2.70 \\
(0.39)\end{array}$ & $\begin{array}{l}3.49 \\
(0.12)\end{array}$ \\
\hline $\begin{array}{l}\text { Absolute Wage } \\
\text { Difference Squared }\end{array}$ & & $\begin{array}{l}-0.23 \\
(0.04)\end{array}$ & $\begin{array}{l}-0.28 \\
(0.04)\end{array}$ & $\begin{array}{l}-0.24 \\
(0.01)\end{array}$ \\
\hline $\begin{array}{l}\text { Standard Deviation of } \\
\text { Wage Difference }\end{array}$ & & & $\begin{array}{l}2.72 \\
(0.42)\end{array}$ & $\begin{array}{l}0.04 \\
(0.07)\end{array}$ \\
\hline $\begin{array}{l}\text { Year dummies? } \\
\text { City dummies? } \\
\text { Adjusted } \mathrm{R}^{2} \\
\text { Number of Observations }\end{array}$ & $\begin{array}{l}\text { yes } \\
\text { yes } \\
.23 \\
27406\end{array}$ & $\begin{array}{l}\text { yes } \\
\text { yes } \\
.23 \\
21863\end{array}$ & $\begin{array}{l}\text { yes } \\
\text { yes } \\
.24 \\
21863\end{array}$ & $\begin{array}{l}\text { yes } \\
\text { yes } \\
.61 \\
21398\end{array}$ \\
\hline
\end{tabular}


Table 9: Non-linear Effects of Exchange Rate Variability

\begin{tabular}{|c|c|c|c|c|}
\hline Log Distance & $\begin{array}{c}\text { Equation } 1 \\
12.11 \\
(2.12)\end{array}$ & $\begin{array}{c}\text { Equation } 2 \\
11.78 \\
(2.30)\end{array}$ & $\begin{array}{c}\text { Equation } 3 \\
12.10 \\
(2.28)\end{array}$ & $\begin{array}{c}\text { Equation } 4 \\
10.22 \\
(0.97)\end{array}$ \\
\hline Log Distance Squared & $\begin{array}{l}-0.57 \\
(0.14)\end{array}$ & $\begin{array}{l}-0.55 \\
(0.15)\end{array}$ & $\begin{array}{l}-0.58 \\
(0.15)\end{array}$ & $\begin{array}{l}-0.46 \\
(0.06)\end{array}$ \\
\hline $\begin{array}{l}\text { Nominal Exchange } \\
\text { Rate Variability }\end{array}$ & $\begin{array}{l}27.69 \\
(2.17)\end{array}$ & $\begin{array}{l}27.51 \\
(2.65)\end{array}$ & $\begin{array}{l}28.12 \\
(2.67)\end{array}$ & $\begin{array}{l}7.79 \\
(0.97)\end{array}$ \\
\hline $\begin{array}{l}\text { Nominal Exchange } \\
\text { Rate Variability Squared }\end{array}$ & $\begin{array}{l}-14.04 \\
(1.54)\end{array}$ & $\begin{array}{l}-12.94 \\
(1.71)\end{array}$ & $\begin{array}{l}-13.17 \\
(1.72)\end{array}$ & $\begin{array}{l}-2.95 \\
(0.52)\end{array}$ \\
\hline Hard Peg & $\begin{array}{l}-3.32 \\
(0.64)\end{array}$ & $\begin{array}{l}-1.56 \\
(0.67)\end{array}$ & $\begin{array}{l}-1.95 \\
(0.65)\end{array}$ & $\begin{array}{l}-1.58 \\
(0.42)\end{array}$ \\
\hline CFA & $\begin{array}{l}-1.15 \\
(1.48)\end{array}$ & $\begin{array}{l}-0.64 \\
(1.53)\end{array}$ & $\begin{array}{l}-0.11 \\
(1.50)\end{array}$ & $\begin{array}{l}0.31 \\
(1.26)\end{array}$ \\
\hline U.S. & $\begin{array}{l}-10.50 \\
(0.43)\end{array}$ & $\begin{array}{l}-9.08 \\
(0.47)\end{array}$ & $\begin{array}{l}-8.84 \\
(0.47)\end{array}$ & $\begin{array}{l}-7.62 \\
(0.26)\end{array}$ \\
\hline Euro & $\begin{array}{l}-2.05 \\
(0.56)\end{array}$ & $\begin{array}{l}-0.33 \\
(0.58)\end{array}$ & $\begin{array}{l}0.32 \\
(0.61)\end{array}$ & $\begin{array}{l}-2.95 \\
(0.45)\end{array}$ \\
\hline Weighted Avg. Tariff & $\begin{array}{l}0.44 \\
(0.01)\end{array}$ & $\begin{array}{l}0.43 \\
(0.01)\end{array}$ & $\begin{array}{l}0.40 \\
(0.01)\end{array}$ & $\begin{array}{l}0.38 \\
(0.01)\end{array}$ \\
\hline $\begin{array}{l}\text { Absolute Wage } \\
\text { Difference }\end{array}$ & & $\begin{array}{l}2.72 \\
(0.37)\end{array}$ & $\begin{array}{l}2.47 \\
(0.37)\end{array}$ & $\begin{array}{l}3.46 \\
(0.12)\end{array}$ \\
\hline $\begin{array}{l}\text { Absolute Wage } \\
\text { Difference Squared }\end{array}$ & & $\begin{array}{l}-0.23 \\
(0.03)\end{array}$ & $\begin{array}{l}-0.28 \\
(0.04)\end{array}$ & $\begin{array}{l}-0.26 \\
(0.01)\end{array}$ \\
\hline $\begin{array}{l}\text { Standard Deviation of } \\
\text { Wage Difference }\end{array}$ & & & $\begin{array}{l}2.68 \\
(0.37)\end{array}$ & $\begin{array}{l}0.36 \\
(0.06)\end{array}$ \\
\hline $\begin{array}{l}\text { Year dummies? } \\
\text { City dummies? } \\
\text { Adjusted } \mathrm{R}^{2} \\
\text { Number of Observations }\end{array}$ & $\begin{array}{l}\text { yes } \\
\text { yes } \\
.23 \\
27406\end{array}$ & $\begin{array}{l}\text { yes } \\
\text { yes } \\
.23 \\
21863\end{array}$ & $\begin{array}{l}\text { yes } \\
\text { yes } \\
.24 \\
21863\end{array}$ & $\begin{array}{l}\text { yes } \\
\text { yes } \\
.61 \\
21398\end{array}$ \\
\hline
\end{tabular}


Table 10: Adding City-Pair Random Effects

\begin{tabular}{|c|c|c|c|c|}
\hline Log Distance & $\begin{array}{c}\text { Equation } 1 \\
13.54 \\
(3.33)\end{array}$ & $\begin{array}{c}\text { Equation } 2 \\
13.69 \\
(3.54)\end{array}$ & $\begin{array}{c}\text { Equation } 3 \\
13.56 \\
(3.34)\end{array}$ & $\begin{array}{c}\text { Equation } 4 \\
14.38 \\
(2.65)\end{array}$ \\
\hline Log Distance Squared & $\begin{array}{l}-0.65 \\
(0.20)\end{array}$ & $\begin{array}{l}-0.66 \\
(0.22)\end{array}$ & $\begin{array}{l}-0.66 \\
(0.21)\end{array}$ & $\begin{array}{l}-0.69 \\
(0.16)\end{array}$ \\
\hline $\begin{array}{l}\text { Nominal Exchange } \\
\text { Rate Variability }\end{array}$ & $\begin{array}{l}3.29 \\
(0.73)\end{array}$ & $\begin{array}{l}4.72 \\
(0.86)\end{array}$ & $\begin{array}{l}4.97 \\
(0.85)\end{array}$ & $\begin{array}{l}1.38 \\
(0.20)\end{array}$ \\
\hline Hard Peg & $\begin{array}{l}-4.22 \\
(1.87)\end{array}$ & $\begin{array}{l}-2.65 \\
(1.91)\end{array}$ & $\begin{array}{l}-3.03 \\
(1.81)\end{array}$ & $\begin{array}{l}0.63 \\
(0.91)\end{array}$ \\
\hline CFA & $\begin{array}{l}-1.24 \\
(3.89)\end{array}$ & $\begin{array}{l}-0.76 \\
(3.98)\end{array}$ & $\begin{array}{l}-0.00 \\
(3.75)\end{array}$ & $\begin{array}{l}1.79 \\
(3.02)\end{array}$ \\
\hline U.S. & $\begin{array}{l}-11.97 \\
(1.16)\end{array}$ & $\begin{array}{l}-10.60 \\
(1.19)\end{array}$ & $\begin{array}{l}-10.08 \\
(1.12)\end{array}$ & $\begin{array}{l}-11.19 \\
(0.90)\end{array}$ \\
\hline Euro & $\begin{array}{l}-1.22 \\
(2.20)\end{array}$ & $\begin{array}{l}-0.59 \\
(2.28)\end{array}$ & $\begin{array}{l}-0.29 \\
(2.26)\end{array}$ & $\begin{array}{l}-0.29 \\
(0.56)\end{array}$ \\
\hline Weighted Avg. Tariff & $\begin{array}{l}0.36 \\
(0.01)\end{array}$ & $\begin{array}{l}0.38 \\
(0.02)\end{array}$ & $\begin{array}{l}0.36 \\
(0.02)\end{array}$ & $\begin{array}{l}0.15 \\
(0.01)\end{array}$ \\
\hline $\begin{array}{l}\text { Absolute Wage } \\
\text { Difference }\end{array}$ & & $\begin{array}{l}1.55 \\
(0.28)\end{array}$ & $\begin{array}{l}1.62 \\
(0.28)\end{array}$ & $\begin{array}{l}1.65 \\
(0.08)\end{array}$ \\
\hline $\begin{array}{l}\text { Absolute Wage } \\
\text { Difference Squared }\end{array}$ & & $\begin{array}{l}-0.15 \\
(0.02)\end{array}$ & $\begin{array}{l}-0.21 \\
(0.02)\end{array}$ & $\begin{array}{l}-0.11 \\
(0.01)\end{array}$ \\
\hline $\begin{array}{l}\text { Standard Deviation of } \\
\text { Wage Difference }\end{array}$ & & & $\begin{array}{l}2.68 \\
(0.20)\end{array}$ & $\begin{array}{l}0.63 \\
(0.14)\end{array}$ \\
\hline Year dummies? & yes & yes & yes & yes \\
\hline City dummies? & yes & yes & yes & yes \\
\hline City-pair random effects? & yes & yes & yes & yes \\
\hline Adjusted $\mathrm{R}^{2}$ & .31 & .30 & .30 & .86 \\
\hline Number of Observations & 27406 & 21863 & 21863 & 21398 \\
\hline
\end{tabular}

Robust standard errors are in parenthesis. All equations include city and time fixed effects. The final column designated Equation 4 - reports results from estimation with extreme observations on the dependent variable (above the $99^{\text {th }}$ percentile and below the $1^{\text {st }}$ percentile) dropped. 


\begin{tabular}{|c|c|c|c|}
\hline Log Distance & $\begin{array}{c}\text { Equation } 1 \\
12.68 \\
(2.13)\end{array}$ & $\begin{array}{c}\text { Equation } 2 \\
13.25 \\
(1.32)\end{array}$ & $\begin{array}{c}\text { Equation } 3 \\
10.16 \\
(1.28)\end{array}$ \\
\hline Log Distance Squared & $\begin{array}{l}-0.61 \\
(0.14)\end{array}$ & $\begin{array}{l}-0.66 \\
(0.08)\end{array}$ & $\begin{array}{l}-0.50 \\
(0.08)\end{array}$ \\
\hline $\begin{array}{l}\text { Nominal Exchange } \\
\text { Rate Variability }\end{array}$ & $\begin{array}{l}3.79 \\
(1.14)\end{array}$ & $\begin{array}{l}3.73 \\
(0.50)\end{array}$ & $\begin{array}{l}3.71 \\
(0.50)\end{array}$ \\
\hline CFA & $\begin{array}{l}-0.18 \\
(1.49)\end{array}$ & $\begin{array}{l}0.34 \\
(1.33)\end{array}$ & $\begin{array}{l}-0.39 \\
(1.31)\end{array}$ \\
\hline U.S. & $\begin{array}{l}-10.27 \\
(0.49)\end{array}$ & $\begin{array}{l}-10.25 \\
(0.31)\end{array}$ & $\begin{array}{l}-11.59 \\
(0.35)\end{array}$ \\
\hline Euro & $\begin{array}{l}-3.51 \\
(0.56)\end{array}$ & $\begin{array}{l}-4.32 \\
(0.48)\end{array}$ & $\begin{array}{l}-0.38 \\
(0.48)\end{array}$ \\
\hline Weighted Avg. Tariff & $\begin{array}{l}0.44 \\
(0.01)\end{array}$ & $\begin{array}{l}0.42 \\
(0.01)\end{array}$ & $\begin{array}{l}0.41 \\
(0.01)\end{array}$ \\
\hline Long-Term Peg & $\begin{array}{l}-7.66 \\
(1.38)\end{array}$ & $\begin{array}{l}-7.29 \\
(1.07)\end{array}$ & $\begin{array}{l}-6.19 \\
(0.97)\end{array}$ \\
\hline Currency Board & $\begin{array}{l}-3.16 \\
(0.67)\end{array}$ & $\begin{array}{l}-3.05 \\
(0.47)\end{array}$ & $\begin{array}{l}-3.05 \\
(0.47)\end{array}$ \\
\hline Common Language & $\begin{array}{l}-2.24 \\
(0.32)\end{array}$ & $\begin{array}{l}-2.09 \\
(0.19)\end{array}$ & $\begin{array}{l}-2.10 \\
(0.19)\end{array}$ \\
\hline $\begin{array}{l}\text { High Inflation } \\
\text { Episodes }\end{array}$ & & $\begin{array}{l}374.7 \\
(17.7)\end{array}$ & $\begin{array}{l}374.7 \\
(17.7)\end{array}$ \\
\hline European Union & & & $\begin{array}{l}-5.85 \\
(0.38)\end{array}$ \\
\hline EFTA & & & $\begin{array}{l}-6.73 \\
(1.45)\end{array}$ \\
\hline CEFTA & & & $\begin{array}{l}-3.77 \\
(5.36)\end{array}$ \\
\hline NAFTA & & & $\begin{array}{l}-4.40 \\
(0.51)\end{array}$ \\
\hline Mercosur & & & $\begin{array}{l}-2.09 \\
(1.26)\end{array}$ \\
\hline Adjusted $\mathrm{R}^{2}$ & .23 & .72 & .73 \\
\hline Number of Observations & 27406 & 27406 & 27406 \\
\hline
\end{tabular}

Robust standard errors are in parenthesis. All equations include city and time fixed effects. 
Table 12: City-pair Fixed Effects

\section{$\begin{array}{llll}\text { Equation } 1 & \text { Equation } 2 & \text { Equation } 3 & \text { Equation } 4\end{array}$}

\begin{tabular}{|c|c|c|c|c|}
\hline $\begin{array}{l}\text { Nominal Exchange } \\
\text { Rate Variability }\end{array}$ & $\begin{array}{l}2.51 \\
(0.33)\end{array}$ & $\begin{array}{l}3.33 \\
(0.40)\end{array}$ & $\begin{array}{l}3.50 \\
(0.41)\end{array}$ & $\begin{array}{l}1.30 \\
(0.21)\end{array}$ \\
\hline $\begin{array}{l}\text { High Inflation } \\
\text { Episodes }\end{array}$ & $\begin{array}{l}384.08 \\
(1.33)\end{array}$ & $\begin{array}{l}376.01 \\
(1.51)\end{array}$ & $\begin{array}{l}384.81 \\
(1.46)\end{array}$ & $\begin{array}{l}3.22 \\
(5.99)\end{array}$ \\
\hline Weighted Avg. Tariff & & $\begin{array}{l}0.10 \\
(0.01)\end{array}$ & $\begin{array}{l}0.14 \\
(0.01)\end{array}$ & $\begin{array}{l}0.10 \\
(0.01)\end{array}$ \\
\hline $\begin{array}{l}\text { Absolute Wage } \\
\text { Difference }\end{array}$ & & & $\begin{array}{l}-1.63 \\
(0.17)\end{array}$ & $\begin{array}{l}1.36 \\
(0.09)\end{array}$ \\
\hline $\begin{array}{l}\text { Absolute Wage } \\
\text { Difference Squared }\end{array}$ & & & $\begin{array}{l}0.11 \\
(0.01)\end{array}$ & $\begin{array}{l}-0.08 \\
(0.01)\end{array}$ \\
\hline $\begin{array}{l}\text { Time fixed effects? } \\
\text { City-pair fixed effects? }\end{array}$ & $\begin{array}{l}\text { yes } \\
\text { yes }\end{array}$ & $\begin{array}{l}\text { yes } \\
\text { yes }\end{array}$ & $\begin{array}{l}\text { yes } \\
\text { yes }\end{array}$ & $\begin{array}{l}\text { yes } \\
\text { yes }\end{array}$ \\
\hline Removing outliers? & no & no & no & yes \\
\hline $\begin{array}{l}\text { Adjusted } \mathrm{R}^{2} \\
\text { Number of Observations }\end{array}$ & $\begin{array}{c}.80 \\
36531\end{array}$ & $\begin{array}{c}.79 \\
27406\end{array}$ & $\begin{array}{c}.84 \\
21863\end{array}$ & $\begin{array}{c}.84 \\
21398\end{array}$ \\
\hline
\end{tabular}

Robust standard errors are in parenthesis. All equations include city-pair and time fixed effects. The final column - designated Equation 4 - reports results from estimation with extreme observations on the dependent variable (above the $99^{\text {th }}$ percentile and below the $1^{\text {st }}$ percentile) dropped. 


\section{Appendix Table 1: Prices Studied}

\begin{tabular}{|c|c|}
\hline 1. Apples (1 kg) (supermarket) & 49. Onions (1 kg) (supermarket) \\
\hline 2. Aspirin (100 tablets) (supermarket) & 50. Orange juice (1 l) (supermarket) \\
\hline Bacon $(1 \mathrm{~kg})$ (supermarket) & 51. Oranges $(1 \mathrm{~kg})$ (supermarket) \\
\hline 4. Bananas (1 kg) (supermarket) & 52. Peaches, canned (500 g) (supermarket) \\
\hline 5. Batteries (two, size D/LR20) (supermarket) & 53. Peanut or corn oil (1 l) (supermarket) \\
\hline Beef: filet mignon $(1 \mathrm{~kg})$ (supermarket) & 54. Peas, canned (250 g) (supermarket) \\
\hline 7. Beef: ground or minced (1 kg) (supermarket) & 55. Pork: chops $(1 \mathrm{~kg})$ (supermarket) \\
\hline 8. Beef: roast $(1 \mathrm{~kg})$ (supermarket) & 56. Pork: loin (1 kg) (supermarket) \\
\hline 9. Beef: steak, entrecote (1 kg) (supermarket) & 57. Potatoes (2 kg) (supermarket) \\
\hline 10. Beef: stewing, shoulder (1 kg) (supermarket) & 58. Razor blades (five pieces) (supermarket) \\
\hline 11. Beer, local brand (1 l) (supermarket) & 59. Scotch whisky, six years old (700 ml) (supermarket) \\
\hline 12. Beer, top quality (330 ml) (supermarket) & 60. Sliced pineapples, canned (500 g) (supermarket) \\
\hline 13. Butter, $500 \mathrm{~g}$ (supermarket) & 61. Soap (100 g) (supermarket) \\
\hline 14. Carrots $(1 \mathrm{~kg})$ (supermarket) & 62. Spaghetti (1 kg) (supermarket) \\
\hline 15. Cheese, imported (500 g) (supermarket) & 63. Sugar, white (1 kg) (supermarket) \\
\hline 16. Chicken: fresh $(1 \mathrm{~kg})$ (supermarket) & 64. Tea bags ( 25 bags) (supermarket) \\
\hline 17. Chicken: frozen (1 kg) (supermarket) & 65. Toilet tissue (two rolls) (supermarket) \\
\hline 18. Cigarettes, local brand (pack of 20) (supermarket) & 66. Tomatoes $(1 \mathrm{~kg})$ (supermarket) \\
\hline 19. Cigarettes, Marlboro (pack of 20) (supermarket) & 67. Tomatoes, canned (250 g) (supermarket) \\
\hline 20. Coca-Cola (1 l) (supermarket) & 68. Tonic water $(200 \mathrm{ml})$ (supermarket) \\
\hline 21. Cocoa (250 g) (supermarket) & 69. Toothpaste with fluoride (120 g) (supermarket) \\
\hline 22. Cognac, French VSOP (700 ml) (supermarket) & 70. Vermouth, Martini \& Rossi (1 l) (supermarket) \\
\hline 23. Cornflakes (375 g) (supermarket) & 71. White bread, $1 \mathrm{~kg}$ (supermarket) \\
\hline 24. Dishwashing liquid $(750 \mathrm{ml})$ (supermarket) & 72. White rice, $1 \mathrm{~kg}$ (supermarket) \\
\hline 25. Drinking chocolate (500 g) (supermarket) & 73. Wine, common table (1 l) (supermarket) \\
\hline 26. Eggs (12) (supermarket) & 74. Wine, fine quality (700 ml) (supermarket) \\
\hline 27. Facial tissues (box of 100) (supermarket) & 75. Wine, superior quality $(700 \mathrm{ml})$ (supermarket) \\
\hline 28. Flour, white (1 kg) (supermarket) & 76. Yoghurt, natural (150 g) (supermarket) \\
\hline 29. Fresh fish (1 kg) (supermarket) & 77. Boy's dress trousers (chain store) \\
\hline 30. Frozen fish fingers $(1 \mathrm{~kg})$ (supermarket) & 78. Boy's jacket, smart (chain store) \\
\hline 31. Gin, Gilbey's or equivalent (700 ml) (supermarket) & 79. Business shirt, white (chain store) \\
\hline 32. Ground coffee (500 g) (supermarket) & 80. Business suit, two piece, medium weight (chain store) \\
\hline 33. Ham: whole (1 kg) (supermarket) & 81. Child's jeans (chain store) \\
\hline 34. Hand lotion (125 ml) (supermarket) & 82. Child's shoes, dress wear (chain store) \\
\hline 35. Insect-killer spray (330 g) (supermarket) & 83. Child's shoes, sportswear (chain store) \\
\hline 36. Instant coffee (125 g) (supermarket) & 84. Cost of six tennis balls e.g., Dunlop, Wilson (average) \\
\hline 37. Lamb: chops (1 kg) (supermarket) & 85. Dress, ready to wear, daytime (chain store) \\
\hline 38. Lamb: leg (1 kg) (supermarket) & 86. Fast food snack: hamburger, fries and drink (average) \\
\hline 39. Lamb: Stewing (1 kg) (supermarket) & 87. Frying pan (Teflon or good equivalent) (supermarket) \\
\hline 40. Laundry detergent (3 l) (supermarket) & 88. International foreign daily newspaper (average) \\
\hline 41. Lemons (1 kg) (supermarket) & 89. Kodak colour film (36 exposures) (average) \\
\hline 42. Lettuce (one) (supermarket) & 90. Men's raincoat, Burberry type (chain store) \\
\hline 43. Light bulbs (two, 60 watts) (supermarket) & 91. Men's shoes, business wear (chain store) \\
\hline 44. Lipstick (deluxe type) (supermarket) & 92. Socks, wool mixture (chain store) \\
\hline 45. Liqueur, Cointreau (700 ml) (supermarket) & 93. Tights, panty hose (chain store) \\
\hline 46. Milk, pasteurised (1 l) (supermarket) & 94. Women's cardigan sweater (chain store) \\
\hline 47. Mineral water (1 l l) (supermarket) & 95. Women's shoes, town (chain store) \\
\hline
\end{tabular}


Appendix Table 2: Cities Included

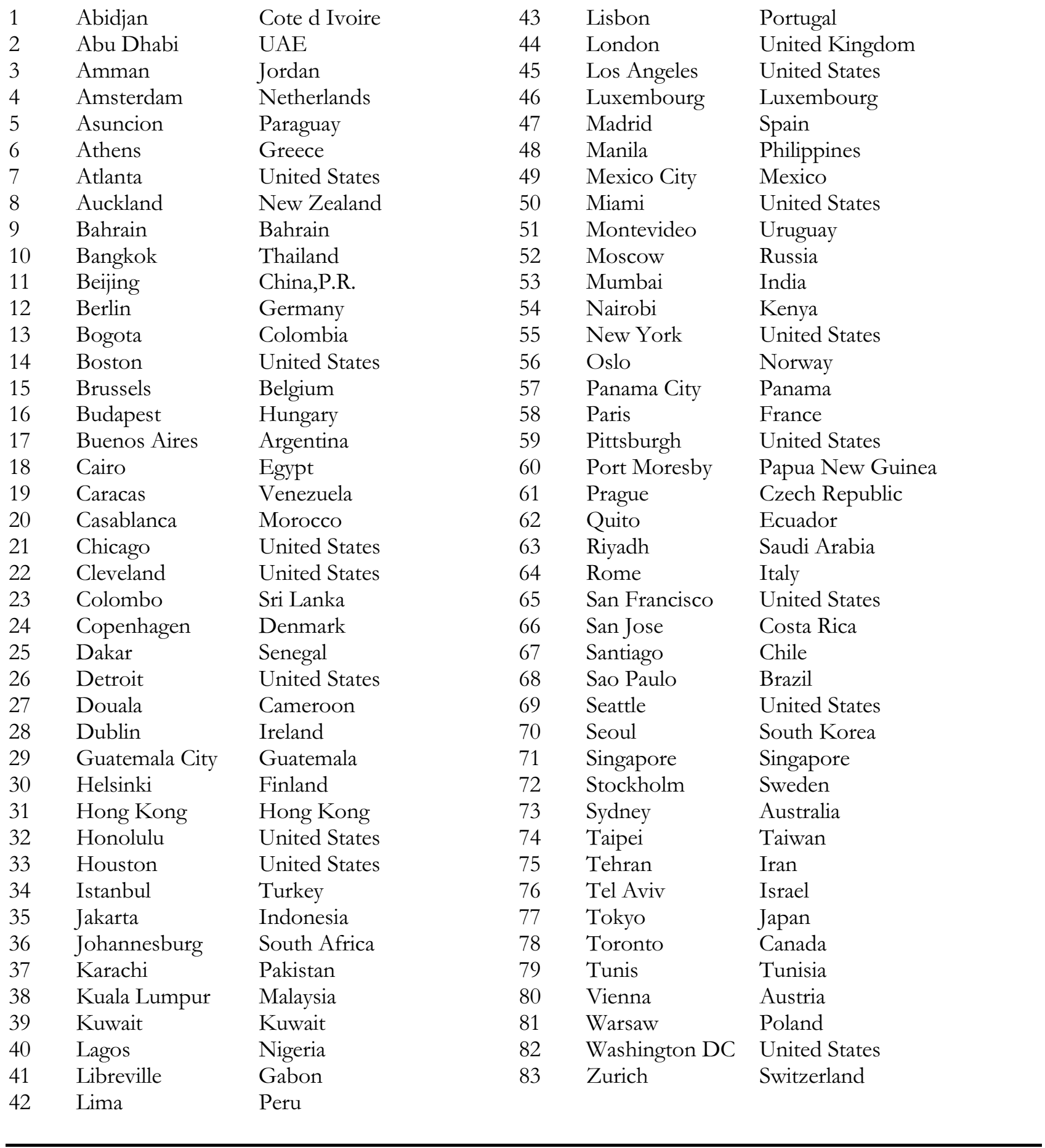


Figure 1: Intercity Price Comparisons

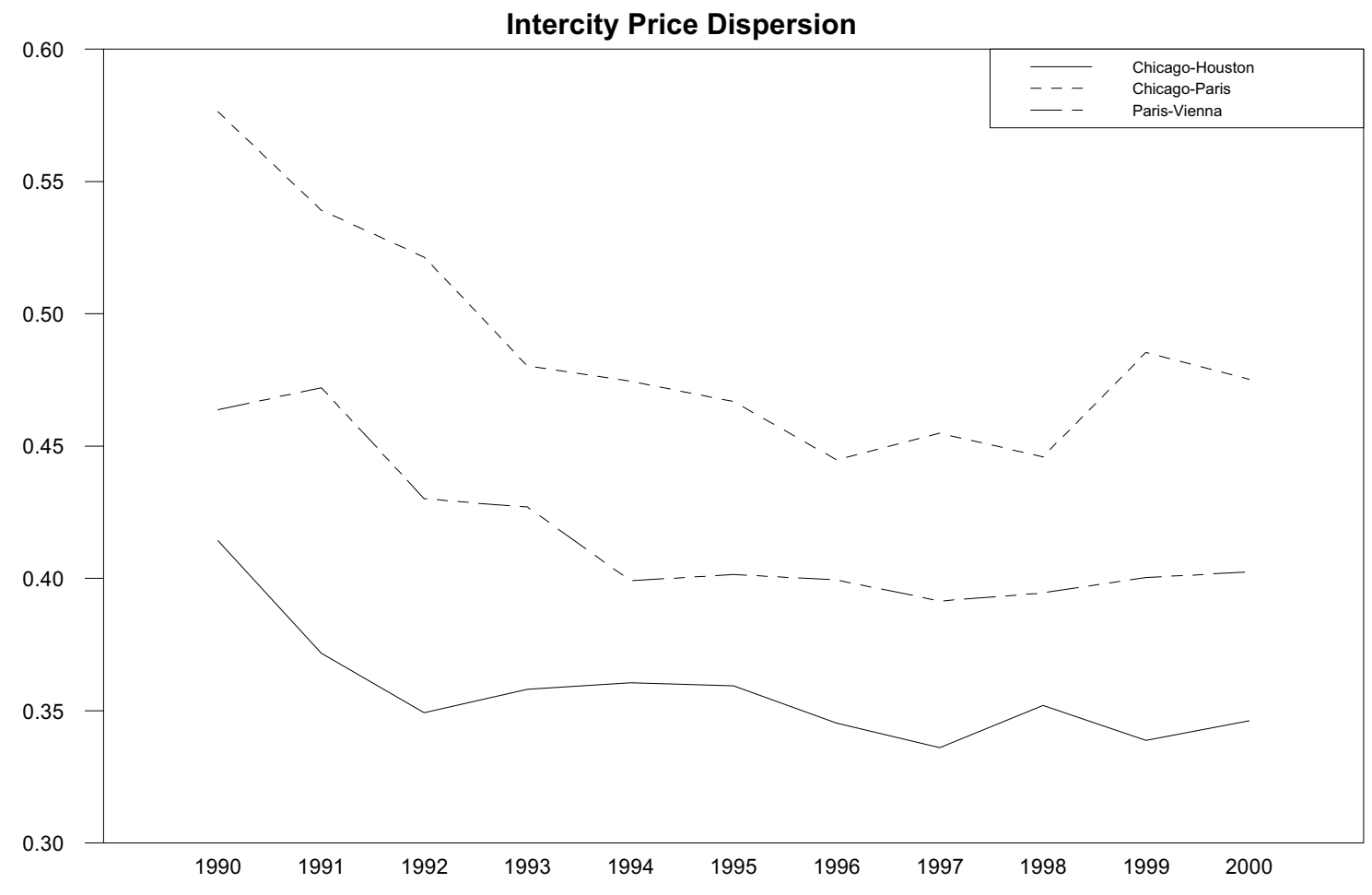




\section{References}

Crucini, Mario, Chris Telmer, and Marios Zachariadis, 2000, "Dispersion in Real Exchange Rates", Vanderbilt University working paper.

Engel, Charles, 1999, “Accounting for U.S. Real Exchange Rate Changes”, Journal of Political Economy, V107, pp. 507-38.

Engel, Charles, and John Rogers, 1996, "How Wide is the Border?" American Economic Review, 86:5, pp. 1112-1125.

Feldstein, Martin, 1997, “The Political Economy of the European Economic and Monetary Union: Political Sources of an Economic Liability”, Journal of Economic Perspectives, 11:4, pp. 23-42.

Frankel, Jeffrey, and Andrew Rose, 2000, "Estimating the Effect of Currency Unions on Trade and Output”, NBER Working Paper \#7857, August.

Helliwell, John, 1998, How Much Do National Borders Matter? DC: Brookings Institution Press.

McCallum, John, 1995, “National Borders Matter: Canada-U.S. Regional Trade Patterns”, American Economic Review, 85:3, pp. 615-23

Mussa, Michael, 1986,Nominal Exchange Rate Regimes and the Behavior of Real Exchange Rates: Evidence and Implications, Carnegie Rochester Conference Series on Public Policy, 24: 117-214.

O'Connell, Paul, and Shang-Jin Wei, 2000, “The Bigger They Are, The Harder They Fall: How Price Differences Across U.S. Cities Are Arbitraged?”, forthcoming, Journal of International Economics.

Parsley, David, and Shang-Jin Wei, 1996, "Convergence to the Law of One Price without Trade Barriers or Currency Fluctuations”, Quarterly Journal of Economics, 111:4, pp. 1211-36.

Parsley, David, and Shang-Jin Wei, 2001, "Explaining the Border Effect: The Role of Exchange Rate Variability, Shipping Costs, and Geography", NBER Working Paper \#7836, August 2000, (with Shang-Jin Wei), forthcoming, Journal of International Economics.

Richardson, J. David, 1978, "Some Empirical Evidence on Commodity Arbitrage and the Law of One Price," Journal of International Economics, VIII, 341-51.

Rogers, John, 2001, "Price Level Convergence, Relative Prices, and Inflation in Europe", International Finance Discussion Paper \#699. March.

Rogers, John, and Michael Jenkins, 1994, "Haircuts or Hysteresis? Sources of Movements in Real Exchange Rates, Journal of International Economics, 38 (3-4), May 1995, pages 339-60.

Rose, Andrew, 2000, “One Money, One Market: Estimating the Effect of Common Currencies on Trade”, Forthcoming, Economic Policy.

Rose, Andrew, and Charles Engel, 2000, "Currency Unions and International Integration”, CEPR discussion paper 2659.

Rose, Andrew, and Eric van Wincoop 2001, "National Money as a Barrier to Trade: The Real Case for Monetary Union", forthcoming, American Economic Review.

Wei, Shang-Jin, 1996, "Intra-national versus International Trade: How Stubborn Are Nations in Global Integration?”, NBER Working Paper 5531, April. 